\title{
ВИХОВНИЙ АСПЕКТ У ТРИГОНАЛЬНИХ ШАХАХ
}

\section{Синьов О. С.}

здобувач третього (освітньо-наукового) рівня вищої освіти кафедри філософії та теології, Бєлгородський державний університет

Розглядається роль шахів як мікромодель людських відносин і на цій основі досліджуються умови їх використання у формуванні взаємовідносин між людьми, моральних иінностей та світогляду на соціальні проиеси. Особливо изе стосується тригональних шах. В протилежність класичним шахам, де изінуються якості бориів, наџілених на суперництво і конфронтацію, в тригональних шахах є можливість виховувати співпрацюю на основних цінностях життя.

Ключові слова: тригональні шахи, взаємовідносини, мораль, життєві ичінності, співпрацяя.

The role of chess as a micromodel of human relations is considered and on this basis the conditions of their use in formation of mutual relations between people, moral values and world outlook on social processes are investigated. This is especially true of trigonal chess. In contrast to classical chess, where the qualities of fighters aimed at rivalry and confrontation are valued, in trigonal chess there is an opportunity to cultivate cooperation on the basic values of life.

Key words: trigonal chess, relationships, morality, life values, cooperation.

Про походження шахів говорять стародавні літературні джерела (легенди). У вигляді гри шахам вже понад 2000 років, але, як засіб виховання людини, як модель взаємовідносин, вони мало вивчені сучасною наукою. В шахах відбиваються різні шари суспільства: рядові, кіннота, інші війська, фортеці, король і королева. Навіть і зараз ці складові присутні в суспільному бутті.

Використовуючи метод аналогії, можна застосувати концепцію симбіозу для опису ситуацій, що виникають в процесі гри в Тригональні шахи. Поняття симбіозу взято нами з біології для опису процесів в суспільстві в силу того, що проглядається певна схожість між взаємовідносинами біологічних об'єктів і соціальних. Проведемо порівняльний аналіз тригональних і класичних шахів на предмет формування системи цінностей у гравців. 
Основи вчення про взаємодопомогу, як окремий випадок симбіозу, заклали в другій половині XIX століття незалежно один від одного російський філософ П. А. Кропоткін і зоолог доктор філософії К. Ф. Кесслер, а також німецький ботанік і мікробіолог Г. А. де Барі, який запропонував терміни «симбіоз» і «мутуалізм». На думку Кропоткіна, етика $\epsilon$ «найкращою зброєю в великій боротьбі за існування, яка постійно ведеться тваринами проти клімату, повеней, буревіїв, буранів, морозу і т. п.» [1, с. 14]. Петро Кропоткін доводить, що в природі лише 3 першого погляду перемагає хижак, що насправді в природі «безліч видів безумовно слабких», які набагато краще хижаків «процвітають в боротьбі за існування, і завдяки властивим їм комунікабельності і взаємному захисту вони навіть витісняють суперників і ворогів, незрівнянно краще їх озброєних. Такими є мурахи, бджоли, голуби, гризуни, олені ... і так далі» [1, с. 16]. Практика взаємодопомоги в природі завжди веде до прогресивного розвитку. Взаємодопомога дає «такі переваги видам тварин, які практикують ㄲi, що зовсім змінює співвідношення сил не на користь хижаків» [2, с. 264].

Конфронтація - навпаки, поняття про відносини, що містять протиборство, протиставлення, зіткнення соціальних систем, інтересів, переконань. Конфронтація породжує конфлікт. 3 різновидів конфлікту нас цікавить, в першу чергу, соціальний конфлікт, коли людина кидає виклик іншій людині, групі осіб або суспільству. Крайній прояв конфлікту — це знищення однією зі сторін конфлікту іншої [3].

Розглянемо і порівняємо взаємини в двох змодельованих в шахах спільнотах. Одна складається з двох гравців класичної шахової партії, а інша — 3 трьох гравців, що грають в Тригональні шахи [4]. Шахова партія має на увазі тимчасове об'єднання гравців в колектив, який за умовами гри змушений взаємодіяти в різних варіантах. Гравців ми будемо розглядати як тимчасове співтовариство, в якому проявляються взаємодії. Шахи виступають як ініціатор і регулятор міжособистісних стосунків.

Які варіанти взаємодії представляє нам гра в класичні шахи? Суперництво, боротьба, конфронтація, прагнення до домінування, і так далі. Активно практикуючи гру в шахи один на один, ми тренуємо і виховуємо в собі перераховані вище якості. Повторюючи з разу в раз певні моделі поведінки, ми формуємо в свідомості стійкі патерни, які несвідомо проявляться в нашій повсякденній діяльності. $Є$ такий ви- 
Розділ II. Особистісні та соціальні детермінанти духовно-інтелектуального виховання і навчання в системі неперервної освіти слів: «Посієш вчинок - пожнеш звичку, посієш звичку — пожнеш характер, посієш характер - пожнеш долю». Звичка - друга натура, і шахісти виховують в собі борців, націлених на суперництво і конфронтацію.

Стереотип поведінки людини, який формується в ігровому процесі, спрямований на утвердження власної переваги в будь-яких умовах, зрештою стає поведінкової нормою. Звідси випливає, зокрема, питання про те, з якого віку можна буде залучати дітей до вивчення шахів і участі в шахових заходах. Якщо між ними буде 3 дитинства боротьба, суперництво, протистояння і тому подібні відносини, та до того ж посилені слов'янським максималізмом, то кому від цього буде користь? Для кооперації, колективізму і народу общинного типу все це вкрай погано.

Слов'яни історично були общинниками, хоча слід зазначити, що 3 кожним роком ця наша культурна особливість все більше розмивається індивідуалізмом споживчого товариства. Руйнуючи культурні форми поведінки, які склалися за століття існування етносу, пройшли випробування часом і зіграли найважливішу роль для його виживання в складних умовах (природних, історичних і т. п.), ми наражаємо на небезпеку існування даного етносу в майбутньому. Неусвідомлене копіювання чужих моделей поводження може привести нас до поглинання іншим культурним полем і виродженню свого. Результат такої діяльності називається «втрата орієнтації» [5].

Класичні шахи виховують егоїста. В самих правилах гри закладена певна філософія поведінки (боротьби і навіть «вбивства»), яка згодом екстраполюється на повсякденну соціальну практику. Відбувається виродження духовності і людяності. Правилами гри не передбачені такі людські якості, як співчуття, дружба, взаємовиручка і т. п. Роз'єднаність суспільства за принципами паразитизму і індивідуалізму нездатна перейти до вищого ступеня розвитку. Як наслідок, ми бачимо прояв негативних поведінкових факторів у людському суспільстві від конкуренції і розгулу злочинності до локальних і світових воєн. Багато вчених вважають, що третє тисячоліття або буде духовним, або його не буде взагалі [6].

Для того щоб змінити світоглядну картину і характер відносин в людському суспільстві, які склалися за тисячоліття, потрібно в свідомість людей плавно вводити поряд 3 вже існуючим розділовим спо- 
лучником «або» - з'єднувальний сполучник «і». Природно, відразу це зробити не вдасться в силу великих інерційних процесів в колективній свідомості. Але робити це потрібно вже зараз. Шахове поле 3 фігурами звичайно, обмежене, як і планета Земля з ії ресурсами. Перебуваючи в умовах однієї замкнутої системи, ми повинні навчитися співпрацювати один з одним - в іншому випадку вичерпання ресурсу на конфлікти або глобальний конфлікт обіцяють нам невтішні перспективи.

Вирішенню такого завдання можуть сприяти модернізовані шахи, що недавно з'явилися на пострадянському просторі. Ці нові шахи називаються «Російські шахи» або Тригональні. Число гравців — три людини одночасно. При грі втрьох у нас непомітно серед усталених стереотипів конфронтації з'являється новий стереотип - співпраця. Це раціональне мислення, в основі якого лежить трійка, непарне число.

В Тригональних шахах через особливості непарного числа гравців завжди з'являється можливість чинити опір більш сильному противнику двома більш слабкими гравцями шляхом союзу або кооперації. Природно, що до розуміння взаємовигідності тимчасового союзу проти більш сильного гравця вони приходять шляхом аналізу поточної ситуації на ігровому полі. Таким чином через гру в свідомість входить інструмент для взаємодії, що дозволяє здійснювати симбіоз в різних його варіантах. Ситуації, що виникають при грі втрьох, змушують нас до симбіозу. Мало того, якщо ми хочемо мати успіх у вигляді перемоги в партії, то ця консолідація обов'язково повинна бути. Вона, звичайно, тимчасова і залежить від ходу ігри. Але такий варіант відносин як співпраця, що практикується в процесі гри, закріплюється у свідомості та підсвідомості і буде проявлятися в повсякденній діяльності гравців. Ще один плюс Тригональних шахів - це можливість створювати свої правила гри. Як інструмент моделювання, вони дуже рухливі, гнучкі і пристосовуються під опис будь-яких ситуацій. На сьогодні налічують приблизно 200 варіантів правил гри в Тригональні шахи, і це не дивлячись на їх молодий вік.

Різний характер відносин від контрактації до співдружності відсуває в бік формулу, по якій «життя — це боротьба». Але в житті багато всього крім боротьби. В Тригональних шахах створюється альтернативний варіант гри, в якому співдружність підживлює життя у всіх його проявах і формах, в той час як у класичних шахах формується 
установка тільки на знищення. У конфронтаційних процесах немає ні симбіозу, ні об'єднання, ні виходу на взаємодію, на стійкість структури і появу нового. I навпаки, в співдружності всі ці явища дають підвищення рівня системної організації і появі нових якостей, яких раніше не було в окремо взятих елементів [7].

Вивчаючи Тригональні шахи, ми знайдемо багато цікавих питань для філософів, культурологів та психологів. Тригональні шахи відкривають нові можливості у формуванні світогляду людини, в якому домінує ціннісна установка на створення і збереження життя.

\section{Список використаних джерел:}

1. Кропоткін П. А. Етика. Походження і розвиток моралі. Москва : Політіздат, $1991.363 \mathrm{c.}$

2. Розенберг Г. С. Конкуренція і взаємодопомога - дві сторони «медалі» взаємодії популяцій (до 175-річчя від дня народження Петра Олексійовича Кропоткіна і 115-річчя виходу його монографії «Взаємна допомога як фактор еволюції») // Ювілеї і дати. Самарська Лука: проблеми регіональної і глобальної екології. 2018. Т. 28, № 3. С. 262-269.

3. Здравомислов А. Г. Соціологія конфлікту. 3-е изд., доп. і пер. Москва : Аспект-Пресс, 1996. 317 с.

4. Малюта О. М. Гіперкомплексні динамічні системи. Львів : Вища школа, 1989. $118 \mathrm{c}$.

5. Малюта О. М. Система діяльності. Київ : Наукова думка, 1991. 206 с.

6. Бабич В. П., Могилко В. А., Онєгіна В. М. Прикладна онтологія. Харків : Вид-во «Друкарня Мадрид», 2013. 364 с.

7. Малюта О. М. Закономірності системного розвитку. Київ : Наукова думка, 1990. $136 \mathrm{c.}$ 